\section{Kalman Filter or VAR Models to Predict Unemployment Rate in Romania?}

\author{
Mihaela Simionescu \\ Romanian Academy, National Institute for Economic Research, Institute for \\ Economic Forecasting, Bucharest, Romania \\ mihaela_mb1@yahoo.com
}

\begin{abstract}
This paper brings to light an economic problem that frequently appears in practice: For the same variable, more alternative forecasts are proposed, yet the decision-making process requires the use of a single prediction. Therefore, a forecast assessment is necessary to select the best prediction. The aim of this research is to propose some strategies for improving the unemployment rate forecast in Romania by conducting a comparative accuracy analysis of unemployment rate forecasts based on two quantitative methods: Kalman filter and vector-auto-regressive (VAR) models. The first method considers the evolution of unemployment components, while the VAR model takes into account the interdependencies between the unemployment rate and the inflation rate. According to the Granger causality test, the inflation rate in the first difference is a cause of the unemployment rate in the first difference, these data sets being stationary. For the unemployment rate forecasts for 2010-2012 in Romania, the VAR models (in all variants of VAR simulations) determined more accurate predictions than Kalman filter based on two state space models for all accuracy measures. According to mean absolute scaled error, the dynamic-stochastic simulations used in predicting unemployment based on the VAR model are the most accurate. Another strategy for improving the initial forecasts based on the Kalman filter used the adjusted unemployment data transformed by the application of the Hodrick-Prescott filter. However, the use of VAR models rather than different variants of the Kalman filter methods remains the best strategy in improving the quality of the unemployment rate forecast in Romania. The explanation of these results is related to the fact that the interaction of unemployment with inflation provides useful information for predictions of the evolution of unemployment related to its components (i.e., natural unemployment and cyclical component).
\end{abstract}

Keywords: forecasts, accuracy, Kalman filter, Hodrick-Prescott filter, VAR models, unemployment rate

\section{Introduction}

The macroeconomic forecasting process witnessed rapid development because economic policies should be based on anticipations regarding the evolution of the economic indicators of a country or region. This impressive development of forecasting methods brought about a practical problem: Different forecasts are provided for the same indicator, but various forecasting methods are used. In general, international organizations prefer to use quantitative methods to
ORIGINAL SCIENTIFIC PAPER

RECEIVED: FEBRUARY 2015

REVISED: APRIL 2015

ACCEPTED: APRIL 2015

DOI: 10.1515/ngoe-2015-0009

UDK: 330.43:331.56(498)

JEL: E21, E27,C51, C5

\section{NG \\ OE}

NAŠE GOSPODARSTVO OUR ECONOMY

Vol.61: No.3: 2015

pp. 3-21 
construct their predictions. The development of econometrics made it an essential tool in building predictions, even if many experts have contested the utility of econometric models, especially in the context of the recent economic crisis. However, these models should not be neglected. The correct solution is to continue the use of more alternative models while incorporating an accuracy assessment for the economic prognoses in order to select the best prediction. This demarche could be considered a good strategy for improving forecast accuracy, an important goal of contemporary economists mainly because the cause of the recent global crisis was the high uncertainty of macroeconomic forecasts.

The literature provides many quantitative tools for predicting macroeconomic indicators like the unemployment rate. For this indicator, the Kalman filter could also be used in making predictions. This method is usually applied in determining the natural unemployment rate, the value for which we have a reasonable level or a stability of inflation rate and wages. The Phillips curve used to describe the relationship between inflation and unemployment rate is not checked in Romania, but vector-autoregressive (VAR) models are an efficient method for providing evidence of the interdependences between the two variables.

The objective of this research is to conduct a comparative analysis of unemployment rate forecasts based on two econometric methods: Kalman filter and VAR models. The best method is actually a strategy of improving the predictions' accuracy by choosing the most suitable quantitative forecasting method. Moreover, we add another perspective to improve the predictions' accuracy. We also propose improving a certain method by making a suitable transformation of that method. In this case, the Kalman filter to make predictions is applied to the transformed data series based on another filter (i.e., the Hodrick-Prescott filter). Thus, a double adjustment is made to the data. The proposed state space model used in the literature for predicting the unemployment rate is applied to the Romania data. If this model is not valid, another one is chosen to fit the data.

The organization of this research is as follows: After a brief review of the literature presenting the quantitative methods used in predicting the unemployment rate, we explain the methodology used. Predictions are made for the unemployment rate in Romania from 2010 to 2012 using the Kalman filter and VAR models, and the steps for building these forecasts are presented in detail. The accuracy evaluation is based on common accuracy measures that lead us to determine the superiority of a certain method.

\section{Literature}

The accuracy of unemployment rate forecasts should be known by governmental decision makers, placement agency workforce, researchers interested in the labor market, and even employees and unemployed people. It is a subject of interest for the overall public opinion. Many studies have treated the problem of the accurate evaluation of macroeconomic forecasts, but only a few of them are related to unemployment predictions.

Camba-Mendez (2012) built conditional forecasts using VAR models and Kalman filter techniques. Kishor and Koenig (2012) made predictions for macroeconomic variables like unemployment rate using VAR models and taking into account that data are subject to revisions. Sermpinis, Stasinakis, and Karathanasopoulos (2013) made predictions for the unemployment rate in the United States using neural networks and compared the utility of support vector regression (SVR) and the Kalman filter in combining these forecasts. The accuracy was greater for the case of SVR approach. Smooth transition vector error-correction models were used by Milas and Rothman (2008) to predict the unemployment rate in numerous countries; for the United States, the pooled predictions based on the median value of point forecasts generated by the linear and STVECM forecasts outperformed the naïve predictions. Proietti (2003) compared the accuracy of several predictions based on linear unobserved components models for the monthly unemployment rate in the United States, concluding that the shocks are not persistent during the business cycle.

Van Dijk, Teräsvirta, and Franses (2000) used a logistic smooth transition autoregressive model to predict the Organization for Economic Cooperation and Development (OECD) countries, with their forecasts outperforming the naïve predictions. Franses, Paap, and Vroomen (2004) assessed the accuracy of unemployment rate forecasts of three G7 countries using an autoregressive time-series model with time-varying parameters; this variation depended on a linear indicator variable.

Kurita (2010) showed that ARFIMA model forecasts for Japan's unemployment rate outperformed the AR(1) model predictions. Allan (2013) improved the accuracy of OECD unemployment forecasts for G7 countries by applying the combination technique. The researcher used two types of methods to assess the accuracy: quantitative techniques and qualitative accuracy methods.

A detailed study regarding unemployment forecasts and predictions performance carried out by Barnichon and 
Nekarda (2012) resulted in a model for the unemployment rate whose predictions outperformed the results offered by classical time-series or by the Survey and Professional Forecasters and Federal Reserve Board. Franses, McAleer, and Legerstee (2012) evaluated the performance of unemployment forecasts made by staff of the Federal Reserve Board and the Federal Open Market Committee (FOMC); the Diebold-Mariano test indicated insignificant differences in terms of forecast accuracy.

Heilemann and Stekler (2013) offered several reasons for the lack of accuracy of G7 predictions in the last 50 years. They identified one continuous critique brought to macro-econometric models and forecasting techniques, but also concluded that the accuracy expectations are not realistic. Other aspects of the forecasts' failure related to forecasts' bias, data quality, the forecasting procedure, type of predicted indicators, and the relationship between forecast accuracy and forecast horizon.

The accuracy of forecasts based on VAR models can be measured using the trace of the mean-squared forecasts error matrix or generalized forecasts error second moment (Clements \& Hendry, 2003). Robinson (1998) demonstrated better accuracy for predictions of some macroeconomic variables based on VAR models compared to other models, like transfer functions. Finally, Lack (2006) found that combined forecasts based on VAR models are a good strategy for improving predictions’ accuracy.

\section{Methodology}

The Kalman filter is an econometric method for predicting the endogenous variables and for adjusting the estimated parameters in forecast equations. There are two systems of equations: a system of prediction equations and a system of update equations.

The stages for applying the Kalman filter are as follows:

1. Estimating endogenous variables values using available prior information.

2. Adjusting estimated parameters using adjustment equations and computing prediction errors.

A state space model includes two equations:

Measurement equation (relationship between observed and unobserved variables): $y_{t}=H_{t} \beta_{t}+A z_{t}+e_{t}$

Transition equation (dynamic of state (unobserved)): $\beta_{t}=\mu+F \beta_{t-1}+v_{t}$

$$
\begin{array}{ll}
y_{t} & - \text { data series } \\
z_{t} & - \text { observed explanatory variables } \\
H_{t} & - \text { variable coefficients of unobserved series } \\
\beta_{t}, A, \text { and } F & - \text { constant coefficients } \\
e_{t} \text { and } v_{t} & - \text { shocks }
\end{array}
$$

Assumptions

$$
\begin{aligned}
& e_{t}^{\sim \text { iid. }} N(0, R) \\
& v_{t} \sim \text { iid. } N(0, Q) \\
& E\left(e_{t}, v_{t}\right)=0
\end{aligned}
$$

The objectives are:

1. The estimation of state space model parameters

$$
\begin{aligned}
& y_{t}=H \beta_{t}+A z_{t}+e_{t} \\
& \beta_{t}=\mu+F \beta_{t-1}+v_{t} \\
& e_{t} \text { riid. } N(0, R) \\
& v_{t} \text { iid. } N(0, Q)
\end{aligned}
$$

2. Restoration of the unobserved state

$$
\begin{aligned}
& y_{t}=H_{t} \beta_{t}+A z_{t}+e_{t} \\
& \beta_{t}=\mu+F \beta_{t-1}+v_{t} \\
& e_{t} \sim \text { iid. } N(0, R) \\
& v_{t} \sim \text { iid. } N(0, Q) \\
& \beta_{t / t-1} \quad-\text { the estimation of } \beta_{t} \text { latent state } \\
& \text { according to the information until } t-1 \\
& \beta_{t / t} \quad-\text { the estimation of } \beta_{t} \text { state according to } \\
& \text { the information until } t \\
& P_{t / t-1} \quad-\text { the } \beta_{t} \text { covariance according to the } \\
& \text { information until } t-1 \\
& P_{t / t} C \quad-\text { the } \beta_{t} \text { covariance according to the } \\
& \text { information until } t \\
& y_{t / t-1} P \quad-\text { the prediction of } y \text { using the } \\
& \text { information until } t-1 \\
& \eta_{t / t-1}=y_{t}-y_{t / t-1}-\text { error prediction } \\
& f_{t / t-1} \quad-\text { the variance of prediction error }
\end{aligned}
$$

The Kalman filter offers an optimal estimation for $\beta_{t}$, conditioned by the information related to the $H_{t}$ state space parameters: $A, \mu, F, R$, and $Q$. We suppose that $\mu, F, R$, and $Q$ are known.

The recursive Kalman filters involve three stages:

1. We start with the supposed values at the initial moment $0: \beta_{0 / 0}$ and $P_{0 / 0}$.

2. The prediction: the optimal prediction $y_{1 / 0}$ at moment 1 , using $\beta_{1 / 0^{*}}$ 
3. The update: the calculation of the prediction error, using the observed value for $y$ at moment 1

$$
\eta_{1 / 0}=y_{1}-y_{1 / 0}
$$

The information included in the prediction error has data that can be recovered for redefining our assumption regarding the value that $\beta$ could have

$$
\beta_{1 / 1}=\beta_{1 / 0}+K_{t} \eta_{1 / 0}
$$

$K_{t}$ - the Kalman gain (the importance accorded to the new information).

The predicted values:

$$
\begin{aligned}
& \beta_{t / t-1}=\mu+F \beta_{t-1 / t-1} \\
& P_{t t-1}=F P_{t-1 / t-1} F^{\prime}+Q
\end{aligned}
$$

The prognosis for $y$ and the error prediction are:

$$
\begin{aligned}
& \eta_{t t-1}=y_{t}-y_{t / t-1}=y_{t}-x_{t} \beta_{t / t-1} \\
& f_{t / t-1}=x_{t} P_{t t-1} x_{t}^{\prime}+R
\end{aligned}
$$

The update:

$$
\begin{aligned}
& \beta_{t / t}=\beta_{t / t-1}+K_{t} \eta_{t / t-1} \\
& P_{t / t}=P_{t / t-1}-K_{t} x_{t} P_{t / t-1}
\end{aligned}
$$

Kalman gain: $K_{t}=P_{t / t-1} x_{t}^{\prime}\left(f_{t / t-1}\right)^{-1}$.

The actual observed unemployment rate is the sum of two components: the natural unemployment rate quantifying the persistent shocks from the supply side (we assume it follows a random path) and the cyclical unemployment that refers to the shocks from the demand side, which are limited as persistence (this component exhibits serial correlation). Some authors consider the cyclical unemployment to influence the natural unemployment rate.

$$
\begin{gathered}
u_{t}=u_{t}^{\text {nat }}+\alpha_{t} \\
u_{t}^{n a t}=u_{t-1}^{n a t}+\varepsilon_{t}
\end{gathered}
$$

$$
\begin{aligned}
& \alpha_{t}=\rho \alpha_{t-1}+\omega_{t} \\
& \varepsilon_{t} \sim N\left(0 ; \sigma_{\varepsilon}^{2}\right) \\
& \omega_{t} \sim N\left(0 ; \sigma_{\omega}^{2}\right) \\
& E\left(\varepsilon_{t}, \omega_{t}\right)=0
\end{aligned}
$$

A state space model for the natural unemployment can have the following form:

$u_{t}=Z \beta_{t}, t=1,2, \ldots, T$ (measurement equation)

$$
\begin{aligned}
& Z=\left[\begin{array}{ll}
1 & 1
\end{array}\right], \beta_{t}=\left[\begin{array}{l}
u_{t}^{\text {nat }} \\
\alpha_{t}
\end{array}\right] \\
& \beta_{t}=T \beta_{t-1}+R \vartheta_{t} \text { (transition equation) } \\
& \mathrm{T}=\left[\begin{array}{ll}
1 & 0 \\
0 & \rho
\end{array}\right], \vartheta_{t}=\left[\begin{array}{l}
\varepsilon_{t} \\
\omega_{t}
\end{array}\right]
\end{aligned}
$$

$$
\begin{aligned}
& \varepsilon_{t} \sim N\left(0 ; \sigma_{\varepsilon}^{2}\right) \\
& \omega_{t} \sim N\left(0 ; \sigma_{\omega}^{2}\right) \\
& E\left(\varepsilon_{t}, \omega_{t}\right)=0
\end{aligned}
$$

Under these conditions the Kalman filter generates optimal predictions and updates of the state variables. The Kalman filter determines the estimator of the minimum square error of the state variables vector. The literature has defined two approaches for the estimation of a variable using this filter. The first one assumes that the initial value of the non-stationary state variable can be fixed and unknown. On the other hand, the second approach considers that the initial value is random. The diffuse prior is specified. If we analyze the first observations, the approach is better even if it can generate numerical instability. If $m$ is the number of state variables, we utilize the approach with Koopman, Shepard, and Doornik's (1999)diffuse prior and $m$ predictions are provided. The unknown parameters that will be estimated are $\varepsilon_{t}, \omega_{t}$ and $\rho$. However, some authors give these parameters some reasonable values from the start. For $\rho$, we have to establish the value from the start, and the log-likelihood function is computed. The variance of the shocks coming from the demand side $\left(\sigma_{\omega}^{2}\right)$ is always greater than the variance of supply shocks $\left(\sigma_{\varepsilon}^{2}\right)$.

The Hodrick-Prescott $(H P)$ filter is often used in macroeconomics to extract the trend of the data series and separate the cyclical component of the time series. The resulting smoothed data are more sensitive to long-term changes.

The initial data series is composed of trend and cyclical components:

$\inf f_{t}=r_{t}+c_{t}$

Hodrick and Prescott (1997) suggested the following solution to the minimization problem: 


$$
\min _{\left\{t r_{t}\right\} t=1, T} \sum_{t=1}^{T}\left(i n f_{t}-t r_{t}\right)^{2}+\gamma \sum_{t=2}^{T-1}\left(\nabla^{2} t r_{t+1}\right)^{2}
$$

$\gamma$ - penalty parameter

The solution to the above equation can be written as:

$$
i n f_{t}=\left(\gamma F+I_{T}\right) \cdot t r_{T}
$$

$\inf _{t}$ - vector of the initial data series of the inflation rate

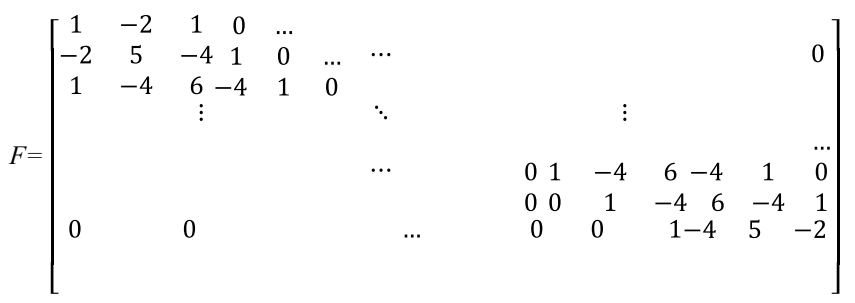

The trend is calculated as: $\operatorname{tr}_{T}=\left[\left(\gamma \cdot F+I_{T}\right)\right]^{-1} \cdot i n f_{T}$.

Razzak (1997) proved that the Hodrick-Prescott filter acts as true filter at the end of the sample and as a smoother over the entire sample. The output gap from the true filter generates better out-of-sample predictions of inflation.

\section{Assessment of Forecasts based on Kalman Filter and VAR Models}

The data series used in this study is represented by the average inflation rate (denoted by $i$ ) and the unemployment rate (denoted by $u$ ) registered in Romania between 1985 and 2012. The average inflation rate is computed as a geometric mean of the monthly indices of the chained base indexes of consumer prices minus the comparison base equal to 100 . The unemployment rate is an indicator used to measure the unemployment intensity, which is computed as a ratio of the number of registered unemployed people and the active population. To model the unemployment rate, we used the data set for the 1985-2009 period, with the one-step-ahead predictions being made for 2010-2012. The data series were provided by a national data source-namely, the National Institute of Statistics. The VAR methodology is based on stationary data sets. The augmented Dickey-Fuller test application (see Appendix 2) provided evidence of the presence of one unit root in each data series. A differentiation of order for one of both data sets led us to stationary data. The new variables are denoted by $d i$ and $d u$, respectively.

Initially we tried to estimate a state space model that explained the theoretical background with a diffuse prior value, but it was not valid (see Appendix 3). The estimations were made in EViews.

$$
\begin{aligned}
& \text { @signal } u=s v 1+s v 2 \\
& \text { @state sv1 }=s v 1(-1)+[v a r=\exp (c(2))] \\
& \text { @state sv2 }=s v 2(-1)+[v a r=\exp (c(1))]
\end{aligned}
$$

The two following models proved to be valid:

@signal $u=s v 1$

$$
\text { @state sv1 }=c(2) * s v 1(-1)+[v a r=\exp (c(1))]
$$

and

$$
\begin{aligned}
& \text { @signal } u=s v 1 \\
& @ \text { state sv1 }=\operatorname{sv1}(-1)+[v a r=\exp (c(1))]
\end{aligned}
$$

Another strategy was based on the adjusted data using the Hodrick-Prescott filter. These new data were used to construct a new state space model using the Kalman technique in the estimation. New predictions were made for 2010-2012. Figure 1 depicts the two components of the data series: the trend and the cycle component.

Figure 1: Decomposition of unemployment rate data series using Hodrick-Prescott filter

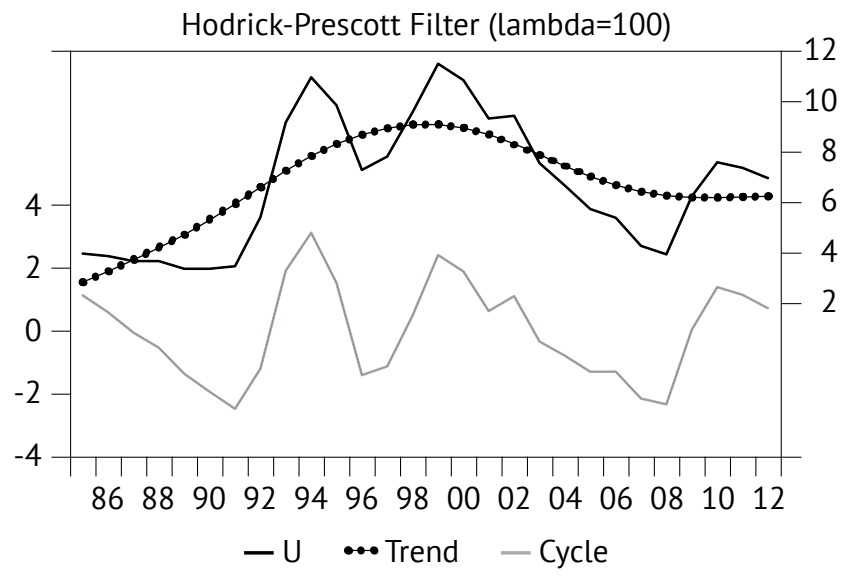

The graph demonstrated an ascending trend until 1998, followed by a slow decrease until the end of the analyzed period, where the trend value was almost $6 \%$.

The Granger causality test was applied for the stationary data series in order to establish if one variable causedanother one. In Granger acceptance, a variable $X$ is a cause for $Y$ if better predictions result when the information provided by $X$ is taken into account. 
Table 1 VAR Granger Causality Tests

\begin{tabular}{lc} 
Hypothesis & Prob. \\
\hline$d i$ does not Granger-cause $d u$ & 0.0042 \\
\hline$d u$ does not Granger-cause $d i$ & 0.0731 \\
\hline
\end{tabular}

Note: $d i$ - differential of inflation rate, $d u$ - differential of unemployment rate

The results of the Granger causality test show that $d i$ is the cause of $d u$, but $d u$ is not the cause of $d i$. Almost all the lag length criteria, except for $\log L$, at the $5 \%$ level indicate that a $\operatorname{VAR}(2)$ model is the best model. All the tests required to check the validity of the estimated $\operatorname{VAR}(2)$ model are displayed in Appendix 1. The form of the VAR model is as follows:

$$
\begin{aligned}
d i= & -0.152048863149 * d i(-1)+0.0573008404372 * d i(-2)- \\
& -0.888383240695 * d u(-1)-0.0437580905699 * d u(-2)+ \\
& +0.0754250947229 \\
d u= & 0.166173513351 * d i(-1)+0.282590212379 * d i(-2)+ \\
& +0.407747364887 * d u(-1)-0.182697623737 * d u(-2)+ \\
& +0.136370162588
\end{aligned}
$$

$V A R$ residual portmanteau tests were used to test the errors'autocorrelation for both identified models. The assumptions of the test were formulated as:

HO: The errors are not auto-correlated.

H1: The errors are auto-correlated.

For the lag 1 up to 12, the probabilities (Prob.) of the tests are greater than 0.05 , which implies that there is not enough evidence to reject the null hypothesis $(\mathrm{HO})$. Thus, we do not have sufficient reason to say that the errors are auto-correlated. After the application of the residual portmanteau test, we concluded that there were no autocorrelations between errors for the $\operatorname{VAR}(2)$ model.

The homoscedasticity is checked using a VAR residual LM test for the $\operatorname{VAR}(2)$ model. If the value of the $L M$ statistic is greater than the critical value, the errors series is heteroskedastic. The $L M$ test showed a constant variance in the errors because the values were greater than 0.05 for the probability. The residual heteroskedasticity test was applied in two variations: with cross-terms and without cross-terms.

Figure 2: Responses of each variable to their own shocks or other variable shocks

Response to Cholesky One S.D. Innovations +- 2 S.E.
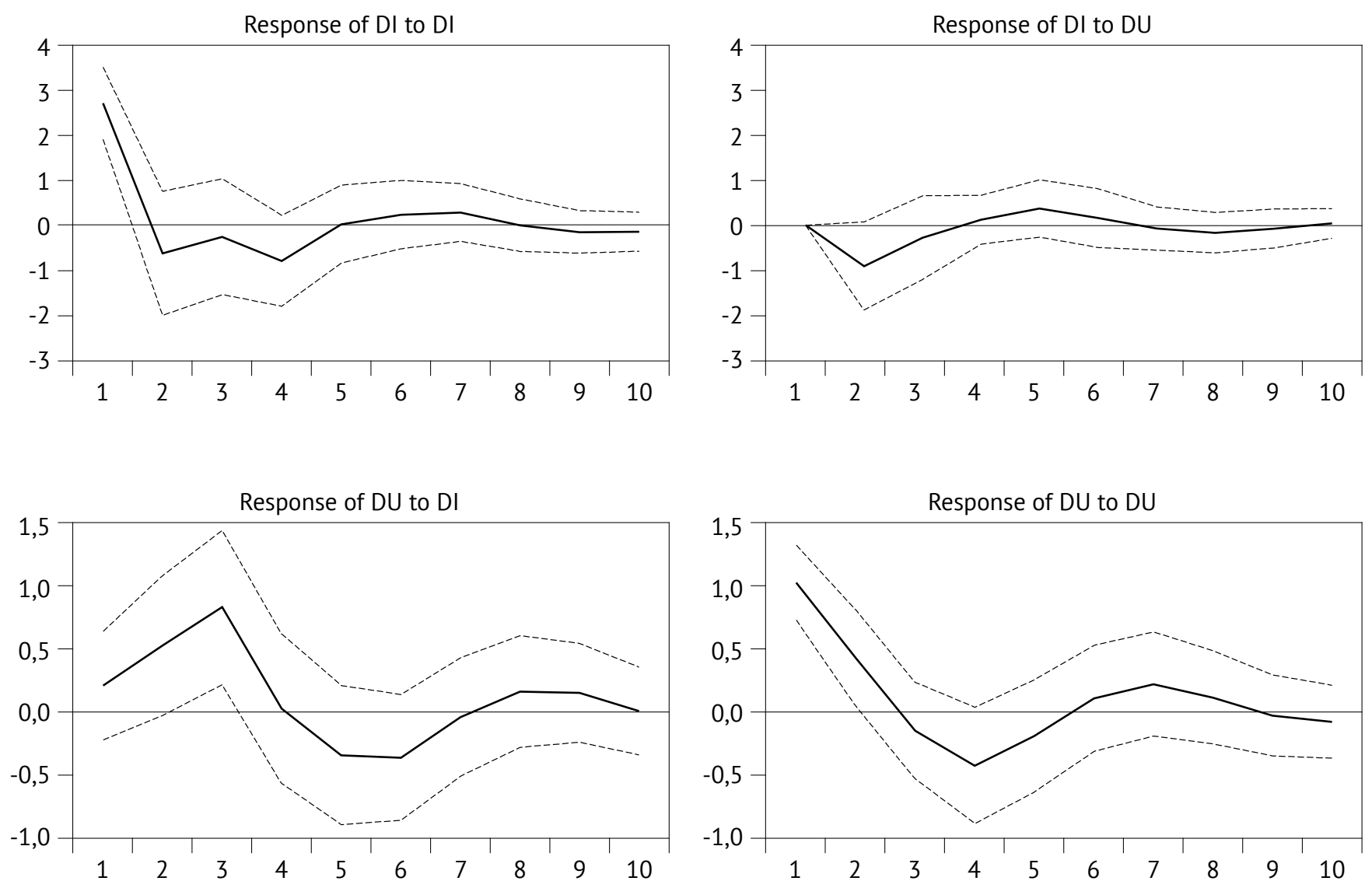
The normality tests were applied under the Cholesky (Lutkepohl) orthogonalization. If the Jarque-Bera statistic is lower than the critical value, there was not enough evidence to reject the normal distribution of the errors. The residual normality test provided probabilities greater than 0.05 , implying that the errors series had a normal distribution when Cholesky (Lutkepohl) orthogonalization was applied. The impulse-response analysis and the decomposition of error variance were applied.

As Figure 2 demonstrates, there the unemployment rate had a stronger response to shocks in inflation than to its own shocks. According to Appendix 1, starting from the third lag the unemployment rate, variance of more than $40 \%$ is explained by the shocks in the inflation rate.

The Kalman filter and the VAR updated models were used to make unemployment rate forecasts for 2010-2012. The accuracy of the forecasts was checked to establish a better forecasting method. For the VAR predictions, four types of scenarios were considered:

\section{- S1: Dynamic-Deterministic Simulation}

- S2: Dynamic-Stochastic Simulation

- S3: Static-Deterministic Simulation

- S4: Static-Stochastic Simulation

We maintained a constant forecast for 2010-2012, when the Kalman filter was applied in the second version. For the other predictions based on the Kalman technique, a decrease in time occurred in the unemployment rate from one year to another. For the different variants of the VAR models' one-step-ahead predictions, the values registered in 2011 were greater than those in 2010 and 2012. The Kalman filter generated predictions less than $7 \%$, while the VAR models forecasts showed a higher degree of variance, being located in the interval [6.6\%; 8.65\%].

The prediction error was computed as the difference between the effective value and the forecasted one of variable $X$, denoted by $e_{x}$. For the number of forecasts on the horizon, it used the notation $n$. The most frequently used statistical measures for assessing forecasts' accuracy, according to Bratu (2012), are root mean squared error (RMSE),

$R M S E=\sqrt{\frac{1}{n} \sum_{j=1}^{n} e_{X}^{2}}$, mean error (ME), ME $=\frac{1}{n} \sum_{j=1}^{n} e_{X}$ and mean absolute error (MAE), MAE $=\frac{1}{n} \sum_{j=1}^{n}\left|e_{X}\right|$.

RMSE is influenced by outliers. These absolute measures depend on the unit of measurement, although this disadvantage is eliminated unless the indicators are expressed as a percentage.

Theil's $U$ statistic, used in making comparisons between predictions, can be used in two variants, which were also presented by the Australian Treasury. The following notations are used:

$a-$ actual/registered value of the analysed variable

$p$ - value for the predicted variable

$t$ - time

$e$ - error (difference between actual value and the forecasted one) $n$ - number of periods

$U_{1}$ takes a value between 0 and 1 . A value closer to zero indicates better accuracy for that prediction. If there are alternative forecasts for the same variable, the one with the lowest value of $U_{1}$ is the most accurate.

$$
U_{1}=\frac{\sqrt{\sum_{t=1}^{n}\left[a_{t}-p_{t}\right]^{2}}}{\sqrt{\sum_{t=1}^{n} a_{t}^{2}+\sqrt{\sum_{t=1}^{n} p_{t}^{2}}}}
$$

Instead of $U_{1}$, the mean absolute scaled error can be computed $\left(M A S E=\right.$ mean $\left.\left|e s_{t}\right|\right)$, the result being the same:

$$
e s_{t}=\frac{e_{t}}{\frac{1}{n-1} \sum_{i=2}^{n}\left|X_{i}-X_{i-1}\right|}
$$

\begin{tabular}{|c|c|c|c|c|c|c|c|c|}
\hline \multicolumn{9}{|c|}{ Forecasting method } \\
\hline Year & $\begin{array}{l}\text { Kalman } \\
\text { filter } 1\end{array}$ & $\begin{array}{l}\text { Kalman } \\
\text { filter } 2\end{array}$ & $\begin{array}{l}\text { Kalman filter } \\
\text { based on } \\
\text { adjusted data } \\
\text { using Hodrick- } \\
\text { Prescott filter } 1\end{array}$ & $\begin{array}{l}\text { Kalman filter } \\
\text { based on } \\
\text { adjusted data } \\
\text { using Hodrick- } \\
\text { Prescott filter } 2\end{array}$ & $\begin{array}{c}V A R(2) \\
\text { models (S1) }\end{array}$ & $\begin{array}{c}V A R(2) \\
\text { models (S2) }\end{array}$ & $\begin{array}{c}V A R(2) \\
\text { models (S3) }\end{array}$ & $\begin{array}{c}V A R(2) \\
\text { models (S4) }\end{array}$ \\
\hline 2010 & 6.1243061140 & 6.275 & 6.293586886 & 6.2306 & 7.39341 & 7.382116478 & 7.39341 & 7.338550845 \\
\hline 2011 & 5.9772311361 & 6.275 & 6.357197078 & 6.2306 & 7.4468778 & 7.447944295 & 7.8966003 & 8.625306581 \\
\hline 2012 & 5.8336881581 & 6.275 & 6.421450187 & 6.2306 & 6.5904475 & 6.648923963 & 7.2046512 & 8.474405877 \\
\hline
\end{tabular}

Table 2 Predictions of Unemployment Rate (\%) based on VAR(2) Models and KalmanFilter

Source: Author's computations. 
Table 3 Accuracy Measures of the Proposed Forecasts

\begin{tabular}{|c|c|c|c|c|c|c|c|c|}
\hline \multirow[b]{2}{*}{$\begin{array}{l}\text { Accuracy } \\
\text { measure }\end{array}$} & \multicolumn{8}{|c|}{ Forecasting method } \\
\hline & $\begin{array}{l}\text { Kalman } \\
\text { filter } 1\end{array}$ & $\begin{array}{l}\text { Kalman } \\
\text { filter } 2\end{array}$ & $\begin{array}{l}\text { Kalman filter } \\
\text { based on } \\
\text { adjusted data } \\
\text { using Hodrick- } \\
\text { Prescott filter } 1\end{array}$ & $\begin{array}{l}\text { Kalman filter } \\
\text { based on } \\
\text { adjusted data } \\
\text { using Hodrick- } \\
\text { Prescott filter } 2\end{array}$ & $\begin{array}{c}V A R(2) \\
\text { models (S1) }\end{array}$ & $\begin{array}{c}\operatorname{VAR}(2) \\
\text { models (S2) }\end{array}$ & $\begin{array}{c}V A R(2) \\
\text { models (S3) }\end{array}$ & $\begin{array}{c}\operatorname{VAR}(2) \\
\text { models (S4) }\end{array}$ \\
\hline ME & 1.3633 & 1.0667 & 0.9843 & 1.1111 & 0.1981 & 0.1820 & -0.1566 & -0.8044 \\
\hline MAE & 1.363258197 & 1.066666667 & 0.984255283 & 0.9843 & 0.2293401 & 0.213967951 & 0.310947167 & 1.111066667 \\
\hline RMSE & 1.3707 & 1.0975 & 1.0320 & 1.1407 & 0.2730 & 0.2480 & 0.3377 & 1.1191 \\
\hline MASE & 0.1029 & 0.0806 & 0.0753 & 0.0840 & 0.0188 & 0.0171 & 0.0227 & 0.0721 \\
\hline $\mathrm{U}_{2}$ & 0.6546 & 0.8031 & 0.8468 & 0.7734 & 0.3497 & 0.6357 & 0.8041 & 0.8607 \\
\hline
\end{tabular}

Source: Author's calculations.

To make comparisons with the naive forecasts, Theil's $U_{2}$ coefficient is used.

$U_{2}=\sqrt{\frac{\sum_{i=1}^{n-1}\left[\frac{p_{t+1}-a_{t+1}}{a_{t}}\right]^{2}}{\sum_{i=1}^{n-1}\left[\frac{a_{t+1}-a_{t}}{a_{t}}\right]^{2}}}$

If $U_{2}=1$, there are no differences in terms of accuracy between the two forecasts compared. If $U_{2}<1$, the forecast compared has a higher degree of accuracy than the naive one. If $U_{2}>1$, the forecast compared has a lower degree of accuracy than the naive one.

According to all accuracy indicators, the forecasts based on $\operatorname{VAR}(2)$ models are more accurate than the Kalman filter predictions. The positive values for mean errors of the Kalam technique forecasts suggest the tendency to underestimate the forecasts for all these methods. In the case of $V A R$ predictions, only the dynamic simulations generated underestimated expectations. It is interesting that a considerable improvement was obtained for the Kalman filter prediction of the first space state model by adjusting the initial data using the Hodrick-Prescott filter. The second scenario of VAR predictions (dynamic-stochastic simulations) was the best according to the MASE indicator used in making comparisons.

\section{Conclusions}

Many quantitative methods are used to make predictions. In this study, we selected two econometric techniques that are rather commonly used in the literature: the Kalman filter method and VAR models. These methods were used to make short-term unemployment rate forecasts for Romania for 2010-2012. According to all accuracy measures, the Kalman technique predictions were underestimated and less accurate than the different scenarios of the VAR model forecasts. It seems that the causality between the first difference data series of inflation and unemployment rate helped improve the forecasting process more. The Kalman filter predictions based only on natural unemployment and cyclical component were not strong enough to generate more accurate forecasts. The superiority of VAR models in forecasting was valid only for this particular case of the Romanian economy, where we demonstrated that inflation is a cause of the unemployment rate's evolution.

Another interesting strategy this article proposed to improve Kalman filter predictions is the application of the technique on adjusted data series based on another filter: the Hodrick-Prescott filter. Applying two filters to the same data set improved the predictions' accuracy in the case of the first proposed state space model.

Another important conclusion is that the classical state space model used in the literature to determine the natural unemployment rate did not provide the expected results for the Romanian economy. Therefore, other, more simplistic state space models were proposed for Romania's unemployment rate.

All in all, this research provides pertinent results regarding the prediction of unemployment rate in Romania, but the study could be improved by comparing other predictive quantitative techniques, like Bayesian VAR or VARMA models. 


\section{References}

1. Allan, G. (2013). Evaluating the usefulness of forecasts of relative growth.Sire Discussion Paper,2013-10,1-26.

2. Barnichon, R., Nekarda, C. J., Hatzius, J., Stehn, S. J., \&Petrongolo, B. (2012). The Ins and Outs of Forecasting Unemployment: Using Labor Force Flows to Forecast the Labor Market [with Comments and Discussion]. Brookings Papers on Economic Activity, 83-131. http://dx.doi.org/10.1353/eca.2012.0018

3. Bratu, M.(2012).The reduction of uncertainty in making decisions by evaluating the macroeconomic forecasts performance in Romania.Economic Research-Scientific Journal, 25(2), 239-262.

4. Camba-Mendez, G. (2012). Conditional forecasts on SVAR models using theKalman filter.Economics Letters, 115(3), 376-378. http:// dx.doi.org/10.1016/j.econlet.2011.12.087

5. Clements, M. P., \& Hendry, D. F. (2003). On the limitations of comparing mean squared forecast errors (with discussion). Journal of Forecasting, 12, 617-639. http://dx.doi.org/10.1002/for.3980120802

6. Franses, P. H., McAleer, M., \&Legerstee, R. (2012).Evaluating macroeconomic forecasts: a concise review of some recent developments.Kier Discussion Paper Series, 821, 1-29.

7. Franses, P. H., Paap, R., \&Vroomen, B. (2004).Forecasting unemployment using an autoregression with censored latent effects parameters.International Journal of Forecasting, 20(2), 255-271. http://dx.doi.org/10.1016/j.ijforecast.2003.09.004

8. Heilemann, U., \&Stekler, H. O. (2013). Has The Accuracy of Macroeconomic Forecasts for Germany Improved?.German Economic Review, 14(2), 235-253. http://dx.doi.org/10.1111/j.1468-0475.2012.00569.x

9. Hodrick, R., \& Prescott, E. C. (1997). Postwar U.S. business cycles: An empirical investigation. Journal of Money, Credit and Banking, 1-16. http://dx.doi.org/10.2307/2953682

10. Kishor, N. K., \& Koenig E. F. (2012).VAR estimation and forecasting when data are subject to revision Journal of Business \& Economic Statistics, 30(2), 181-190.

11. Koopman, S.J., Shephard, N.\&Doornik, J.A. ( 1999). Statistical algorithms for models in state space using SsfPack 2.2.Econometrics Journal, 2(1), 107-160. http://dx.doi.org/10.1111/1368-423X.00023

12. Kurita, T. (2010).A forecasting model for Japan's unemployment rate.Eurasian Journal of Business and Economics, 3(5), 127-134.

13. Lack, C. (2006).Forecasting Swiss inflation using VAR models.Swiss National Bank Economic Studies, 2.

14. Milas, C.,\&Rothman, F. (2008). Out-of-sample forecasting of unemployment rates with pooled STVECM forecasts.International Journal of Forecasting, 24(1), 101-121. http://dx.doi.org/10.1016/j.ijforecast.2007.12.003

15. Proietti, T. (2003). Forecasting the US unemployment rate.Computational Statistics \& Data Analysis, 42(3), 451-476. http://dx.doi. org/10.1016/S0167-9473(02)00230-X

16. Razzak, W. (1997). The Hodrick-Prescott technique: A smoother versus a filter: An application to New Zealand GDP.Economics Letters, 57(2), 163-168. http://dx.doi.org/10.1016/S0165-1765(97)00178-X

17. Robinson, W. (1998). Forecasting inflation using VAR Analysis.Bank of Jamaica.Retrieved from http://www.boj.org.jm/uploads/pdf/ papers_pamphlets/papers_pamphlets_forecasting_inflation_using_var_analysis.pdf

18. Sermpinis, G., Stasinakis, C., \& Karathanasopoulos, A. (2013).Kalmanfilter and SVR combinations in forecasting US unemployment. Artificial Intelligence Applications and InnovationsIFIP Advances in Information and Communication Technology, 412, 506-515.

19. vanDijk, D., Teräsvirta, T., \&Franses, P.H. (2000). Smooth transition autoregressive models-Asurvey of recent developments. Working Paper Series in Economics andFinance, No. 380, Stockholm School of Economics.

\section{Appendix 1}

Tests for Checking the Assumptions Related to the VAR Model

Lag-length criteria

\begin{tabular}{lcccccc}
\hline Lag & LogL & LR & FPE & AIC & SC & HQ \\
\hline 0 & -97.51033 & NA & 19.63724 & 8.653072 & 8.751811 & 8.677905 \\
\hline 1 & -89.69603 & 13.59009 & 14.13464 & 8.321394 & 8.617609 & 8.395891 \\
\hline 2 & -82.84189 & $10.72821^{*}$ & $11.15128^{*}$ & $8.073208^{*}$ & $8.566901^{*}$ & $8.197370^{*}$ \\
\hline
\end{tabular}


Residual Portmanteau test for checking errors' autocorrelation

\begin{tabular}{|c|c|c|c|c|c|}
\hline Lags & $Q$-Stat & Prob. & Adj Q-Stat & Prob. & df \\
\hline 1 & 0.175105 & $N A^{*}$ & 0.183064 & $N^{*}$ & $N A^{*}$ \\
\hline 2 & 1.326585 & $N A^{*}$ & 1.444209 & $N A^{*}$ & $N A^{*}$ \\
\hline 3 & 2.837075 & 0.5855 & 3.181272 & 0.5280 & 4 \\
\hline 4 & 3.579113 & 0.8930 & 4.079529 & 0.8499 & 8 \\
\hline 5 & 5.432702 & 0.9419 & 6.448004 & 0.8918 & 12 \\
\hline 6 & 8.810793 & 0.9210 & 11.01836 & 0.8084 & 16 \\
\hline 7 & 9.136089 & 0.9813 & 11.48598 & 0.9326 & 20 \\
\hline 8 & 11.53810 & 0.9846 & 15.16906 & 0.9157 & 24 \\
\hline 9 & 16.88601 & 0.9508 & 23.95490 & 0.6839 & 28 \\
\hline 10 & 18.92214 & 0.9675 & 27.55730 & 0.6911 & 32 \\
\hline 11 & 19.42491 & 0.9890 & 28.52093 & 0.8081 & 36 \\
\hline 12 & 21.16431 & 0.9937 & 32.15787 & 0.8067 & 40 \\
\hline
\end{tabular}

* The test is valid only for lags larger than the VAR lag order.

$\mathrm{df}$ is degrees of freedom for (approximate) chi-square distribution

Residual LM test for checking errors' homoscedasticity

VAR Residual Serial Correlation LM Tests

Null Hypothesis: no serial correlation at lag order $h$

\begin{tabular}{lll} 
Lags & LM-Stat & Prob \\
\hline 1 & 0.460020 & 0.9773 \\
\hline 2 & 2.681114 & 0.6125 \\
\hline 3 & 2.075462 & 0.7219 \\
\hline 5 & 0.950521 & 0.9172 \\
\hline 6 & 1.816200 & 0.7695 \\
\hline 7 & 3.531397 & 0.4731 \\
\hline 8 & 0.341387 & 0.9870 \\
\hline 9 & 3.978712 & 0.4089 \\
\hline 10 & 6.746046 & 0.1499 \\
\hline 11 & 2.243840 & 0.6910 \\
\hline 12 & 0.547576 & 0.9687 \\
\hline
\end{tabular}

Probs from chi-square with $4 \mathrm{df}$.

VAR Residual Heteroskedasticity Tests

VAR Residual Heteroskedasticity Tests: No cross-terms (only levels and squares)

Joint test:

\begin{tabular}{llc} 
Chi-sq & df & Prob. \\
\hline 25.24139 & 24 & 0.3927 \\
\hline
\end{tabular}

Individual components:

\begin{tabular}{lcccc} 
Dependent & R-squared & $F(8,14)$ & Prob. & Chi-sq(8) \\
\hline res1*res1 & 0.322277 & 0.832175 & 0.5894 & 7.412368 \\
\hline res2*res2 & 0.233480 & 0.533044 & 0.8131 & 5.370029 \\
\hline res2*res1 & 0.625253 & 2.919816 & 0.0383 & 14.38082 \\
\hline
\end{tabular}


VAR Residual Heteroskedasticity Tests: Includes cross-terms Joint test:

\begin{tabular}{lll} 
Chi-sq & df & Prob. \\
\hline 52.21834 & 42 & 0.1342 \\
\hline
\end{tabular}

Individual components:

\begin{tabular}{lccccc} 
Dependent & R-squared & $F(14,8)$ & Prob. & Chi-sq(14) & Prob. \\
\hline res1*res1 & 0.916236 & 6.250420 & 0.0068 & 21.07342 & 0.0998 \\
\hline res2*res2 & 0.523429 & 0.627613 & 0.7870 & 12.03886 & 0.6032 \\
\hline res2*res1 & 0.929029 & 7.480110 & 0.0038 & 21.36766 & 0.0926 \\
\hline
\end{tabular}

Jarque-Bera Test for Checking Normal Distribution

\begin{tabular}{lcccc} 
Component & Skewness & Chi-sq & df & Prob. \\
\hline 1 & 0.400022 & 0.613399 & 1 & 0.4335 \\
\hline 2 & 0.184908 & 0.131066 & 1 & 0.7173 \\
\hline Joint & & 0.744465 & 2 & 0.6892 \\
\hline
\end{tabular}

\begin{tabular}{lcccc} 
Component & Kurtosis & Chi-sq & df & Prob. \\
\hline 1 & 3.034727 & 0.001156 & 1 & 0.9729 \\
\hline 2 & 3.009473 & $8.60 \mathrm{E}-05$ & 1 & 0.9926 \\
\hline Joint & & 0.001242 & 2 & 0.9994 \\
\hline
\end{tabular}

\begin{tabular}{lccc} 
Component & Jarque-Bera & df & Prob. \\
\hline 1 & 0.614555 & 2 & 0.7354 \\
\hline 2 & 0.131152 & 2 & 0.9365 \\
\hline Joint & 0.745707 & 4 & 0.9456 \\
\hline
\end{tabular}

Impulse-Response Analysis

Response of DI:

\begin{tabular}{lcc} 
Period & DI & DU \\
\hline 1 & 2.685611 & 0.000000 \\
\hline 2 & -0.601577 & -0.907380 \\
\hline 3 & -0.239417 & -0.276710 \\
\hline 4 & -0.765368 & 0.120726 \\
\hline 5 & 0.035891 & 0.370063 \\
\hline 7 & 0.245921 & 0.156501 \\
\hline 8 & 0.292615 & -0.074911 \\
\hline 9 & 0.013271 & -0.166930 \\
\hline 10 & -0.134527 & -0.076009 \\
\hline
\end{tabular}

Response of DU:

\begin{tabular}{lcc} 
Period & DI & DU \\
\hline 1 & 0.217511 & 1.021384 \\
\hline 2 & 0.534967 & 0.416467 \\
\hline 3 & 0.837354 & -0.167574 \\
\hline 4 & 0.033907 & -0.446814 \\
\hline 6 & -0.333998 & -0.209706 \\
\hline 7 & -0.352703 & 0.091735 \\
\hline 8 & -0.031785 & 0.206300 \\
\hline 9 & 0.169597 & 0.099136 \\
\hline 10 & 0.159855 & -0.046176 \\
\hline
\end{tabular}


Variance Decomposition of DU:

\begin{tabular}{|c|c|c|c|}
\hline Period & S.E. & DI & DU \\
\hline \multirow[t]{2}{*}{1} & 1.044287 & 4.338332 & 95.66167 \\
\hline & & (8.29004) & (8.29004) \\
\hline \multirow[t]{2}{*}{2} & 1.245058 & 21.51381 & 78.48619 \\
\hline & & (15.6848) & (15.6848) \\
\hline \multirow[t]{2}{*}{3} & 1.509772 & 45.39161 & 54.60839 \\
\hline & & (17.4357) & (17.4357) \\
\hline \multirow[t]{2}{*}{4} & 1.574867 & 41.76315 & 58.23685 \\
\hline & & (16.8917) & (16.8917) \\
\hline \multirow[t]{2}{*}{5} & 1.623495 & 43.53115 & 56.46885 \\
\hline & & $(17.3532)$ & (17.3532) \\
\hline \multirow[t]{2}{*}{6} & 1.663896 & 45.93614 & 54.06386 \\
\hline & & (17.3496) & (17.3496) \\
\hline \multirow[t]{2}{*}{7} & 1.676938 & 45.26035 & 54.73965 \\
\hline & & $(17.4312)$ & (17.4312) \\
\hline \multirow[t]{2}{*}{8} & 1.688405 & 45.65663 & 54.34337 \\
\hline & & $(17.6840)$ & $(17.6840)$ \\
\hline \multirow[t]{2}{*}{9} & 1.696584 & 46.10526 & 53.89474 \\
\hline & & (17.6590) & (17.6590) \\
\hline \multirow[t]{2}{*}{10} & 1.699412 & 45.96038 & 54.03962 \\
\hline & & (17.7893) & (17.7893) \\
\hline
\end{tabular}

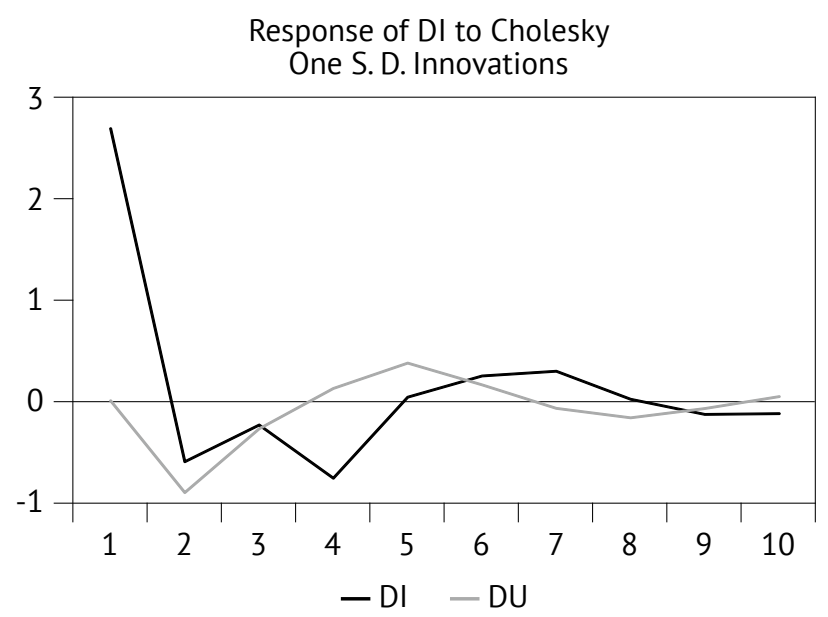

Variance Decomposition of DI:

\begin{tabular}{|c|c|c|c|}
\hline Period & S.E. & DI & DU \\
\hline \multirow[t]{2}{*}{1} & 2.685611 & 100.0000 & 0.000000 \\
\hline & & $(0.00000)$ & $(0.00000)$ \\
\hline \multirow[t]{2}{*}{2} & 2.897885 & 90.19570 & 9.804295 \\
\hline & & (10.1231) & $(10.1231)$ \\
\hline \multirow[t]{2}{*}{3} & 2.920895 & 89.45210 & 10.54790 \\
\hline & & $(9.83838)$ & (9.83838) \\
\hline \multirow[t]{2}{*}{4} & 3.021919 & 89.98595 & 10.01405 \\
\hline & & $(9.22464)$ & $(9.22464)$ \\
\hline \multirow[t]{2}{*}{5} & 3.044705 & 88.65800 & 11.34200 \\
\hline & & $(10.4016)$ & $(10.4016)$ \\
\hline \multirow[t]{2}{*}{6} & 3.058626 & 88.49921 & 11.50079 \\
\hline & & $(10.8627)$ & $(10.8627)$ \\
\hline \multirow[t]{2}{*}{7} & 3.073505 & 88.55088 & 11.44912 \\
\hline & & $(10.8456)$ & $(10.8456)$ \\
\hline \multirow[t]{2}{*}{8} & 3.078063 & 88.29066 & 11.70934 \\
\hline & & $(11.3968)$ & (11.3968) \\
\hline \multirow[t]{2}{*}{9} & 3.081939 & 88.25927 & 11.74073 \\
\hline & & (11.6589) & $(11.6589)$ \\
\hline \multirow[t]{2}{*}{10} & 3.084847 & 88.26568 & 11.73432 \\
\hline & & (11.8730) & (11.8730) \\
\hline
\end{tabular}

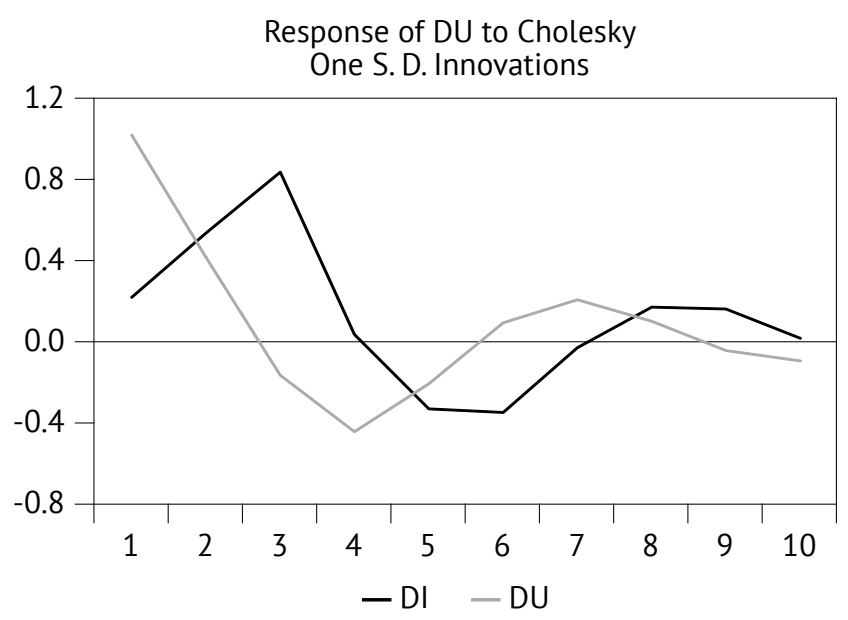




\section{Appendix 2}

ADF Test for Inflation and Unemployment Rate

Null Hypothesis: D(I) has a unit root

Exogenous: Constant

Lag Length: 0 (Automatic_-based on SIC, maxlag=6)

\begin{tabular}{lllc} 
& & $t$-Statistic & Prob. $^{*}$ \\
\hline Augmented Dickey-Fuller test statistic & -5.372594 & 0.0002 \\
\hline Test critical values: & 1\% level & -3.711457 & \\
\hline & 5\% level & -2.981038 & \\
\hline & $10 \%$ level & -2.629906 & \\
\hline
\end{tabular}

*MacKinnon (1996) one-sided p-values.

Augmented Dickey-Fuller Test Equation

Dependent Variable: D(I,2)

Method: Least Squares

\begin{tabular}{|c|c|c|c|c|}
\hline Variable & Coefficient & Std. Error & $t$-Statistic & Prob. \\
\hline $\mathrm{D}(\mathrm{I}(-1))$ & -1.091922 & 0.203239 & -5.372594 & 0.0000 \\
\hline C & -0.024845 & 0.519951 & -0.047783 & 0.9623 \\
\hline R-squared & 0.546011 & \multicolumn{2}{|c|}{ Mean dependent var } & -0.003846 \\
\hline Adjusted R-squared & 0.527095 & \multicolumn{2}{|c|}{ S.D. dependent var } & 3.855228 \\
\hline S.E. of regression & 2.651166 & \multicolumn{2}{|c|}{ Akaike info criterion } & 4.861680 \\
\hline Sum squared resid & 168.6883 & \multicolumn{2}{|c|}{ Schwarz criterion } & 4.958456 \\
\hline Log likelihood & -61.20183 & \multicolumn{2}{|c|}{ Hannan-Quinn criter. } & 4.889548 \\
\hline F-statistic & 28.86477 & \multicolumn{2}{|c|}{ Durbin-Watson stat } & 2.014213 \\
\hline Prob(F-statistic) & 0.000016 & & & \\
\hline
\end{tabular}

Null Hypothesis: D(I) has a unit root

Exogenous: Constant, Linear Trend

Lag Length: 0 (Automatic_-based on SIC, maxlag=6)

\begin{tabular}{lllc} 
& & $t$-Statistic & Prob. $^{*}$ \\
\hline Augmented Dickey-Fuller test statistic & -5.346732 & 0.0010 \\
\hline Test critical values: & 1\% level & -4.356068 & \\
\hline & 5\% level & -3.595026 & \\
\hline & $10 \%$ level & -3.233456 & \\
\hline
\end{tabular}

*MacKinnon (1996) one-sided p-values. 
Augmented Dickey-Fuller Test Equation

Dependent Variable: D(I,2)

\begin{tabular}{|c|c|c|c|c|}
\hline Variable & Coefficient & Std. Error & $t$-Statistic & Prob. \\
\hline $\mathrm{D}(\mathrm{I}(-1))$ & -1.109342 & 0.207480 & -5.346732 & 0.0000 \\
\hline C & 0.640661 & 1.152837 & 0.555725 & 0.5838 \\
\hline @TREND(1985) & -0.045920 & 0.070771 & -0.648849 & 0.5229 \\
\hline R-squared & 0.554172 & \multicolumn{2}{|l|}{ Mean dependent var } & -0.003846 \\
\hline Adjusted R-squared & 0.515405 & \multicolumn{2}{|l|}{ S.D. dependent var } & 3.855228 \\
\hline S.E. of regression & 2.683736 & \multicolumn{2}{|l|}{ Akaike info criterion } & 4.920464 \\
\hline Sum squared resid & 165.6561 & \multicolumn{2}{|l|}{ Schwarz criterion } & 5.065629 \\
\hline Log likelihood & -60.96603 & \multicolumn{2}{|l|}{ Hannan-Quinn criter. } & 4.962266 \\
\hline F-statistic & 14.29471 & \multicolumn{2}{|l|}{ Durbin-Watson stat } & 2.019481 \\
\hline Prob(F-statistic) & 0.000092 & & & \\
\hline
\end{tabular}

Null Hypothesis: D(I) has a unit root

Exogenous: None

Lag Length: 0 (Automatic_-based on SIC, maxlag=6)

\begin{tabular}{lccc} 
& & $t$-Statistic & Prob. $^{*}$ \\
\hline \multicolumn{2}{l}{ Augmented Dickey-Fuller test statistic } & -5.482909 & 0.0000 \\
\hline Test critical values: & $1 \%$ level & -2.656915 & \\
\hline & $5 \%$ level & -1.954414 & \\
\hline & $10 \%$ level & -1.609329 & \\
\hline
\end{tabular}

*MacKinnon (1996) one-sided p-values.

Augmented Dickey-Fuller Test Equation

Dependent Variable: D(I,2)

Method: Least Squares

\begin{tabular}{|c|c|c|c|c|}
\hline Variable & Coefficient & Std. Error & $t$-Statistic & Prob. \\
\hline $\mathrm{D}(\mathrm{I}(-1))$ & -1.091849 & 0.199137 & -5.482909 & 0.0000 \\
\hline R-squared & 0.545968 & Mean dependent var & & -0.003846 \\
\hline Adjusted R-squared & 0.545968 & S.D. dependent var & & 3.855228 \\
\hline S.E. of regression & 2.597725 & Akaike info criterion & & 4.784852 \\
\hline Sum squared resid & 168.7044 & Schwarz criterion & & 4.833240 \\
\hline Log likelihood & -61.20307 & Hannan-Quinn criter. & & 4.798786 \\
\hline Durbin-Watson stat & 2.014156 & & & \\
\hline
\end{tabular}


Null Hypothesis: D(U) has a unit root

Exogenous: Constant

Lag Length: 1 (Automatic_-based on SIC, maxlag=6)

\begin{tabular}{lllc} 
& & $t$-Statistic & Prob. $^{*}$ \\
\hline Augmented Dickey-Fuller test statistic & -4.350208 & 0.0023 \\
\hline Test critical values: & 1\% level & -3.724070 & \\
\hline & 5\% level & -2.986225 & \\
\hline & $10 \%$ level & -2.632604 & \\
\hline
\end{tabular}

*MacKinnon (1996) one-sided p-values.

Augmented Dickey-Fuller Test Equation

Dependent Variable: D(U,2)

Method: Least Squares

\begin{tabular}{|c|c|c|c|c|}
\hline Variable & Coefficient & Std. Error & $t$-Statistic & Prob. \\
\hline $\mathrm{D}(\mathrm{U}(-1))$ & -0.853569 & 0.196213 & -4.350208 & 0.0003 \\
\hline $\mathrm{D}(\mathrm{U}(-1), 2)$ & 0.506854 & 0.184224 & 2.751288 & 0.0117 \\
\hline C & 0.114034 & 0.241543 & 0.472105 & 0.6415 \\
\hline R-squared & 0.465821 & \multicolumn{2}{|c|}{ Mean dependent var } & -0.008000 \\
\hline Adjusted R-squared & 0.417259 & \multicolumn{2}{|c|}{ S.D. dependent var } & 1.571431 \\
\hline S.E. of regression & 1.199591 & \multicolumn{2}{|c|}{ Akaike info criterion } & 3.314005 \\
\hline Sum squared resid & 31.65840 & \multicolumn{2}{|c|}{ Schwarz criterion } & 3.460270 \\
\hline Log likelihood & -38.42506 & \multicolumn{2}{|c|}{ Hannan-Quinn criter. } & 3.354573 \\
\hline F-statistic & 9.592329 & \multicolumn{2}{|c|}{ Durbin-Watson stat } & 2.031800 \\
\hline Prob(F-statistic) & 0.001011 & & & \\
\hline
\end{tabular}

Null Hypothesis: D(U) has a unit root

Exogenous: Constant, Linear Trend

Lag Length: 1 (Automatic_-based on SIC, maxlag=6)

\begin{tabular}{llll} 
& & $t$-Statistic & Prob. $^{*}$ \\
\hline Augmented Dickey-Fuller test statistic & -4.375020 & 0.0100 \\
\hline Test critical values: & 1\% level & -4.374307 & \\
\hline & 5\% level & -3.603202 & \\
\hline & $10 \%$ level & -3.238054 & \\
\hline
\end{tabular}

*MacKinnon (1996) one-sided p-values. 
Augmented Dickey-Fuller Test Equation

Dependent Variable: D(U,2)

Method: Least Squares

\begin{tabular}{|c|c|c|c|c|}
\hline Variable & Coefficient & Std. Error & $t$-Statistic & Prob. \\
\hline $\mathrm{D}(\mathrm{U}(-1))$ & -0.873002 & 0.199542 & -4.375020 & 0.0003 \\
\hline $\mathrm{D}(\mathrm{U}(-1), 2)$ & 0.513185 & 0.186062 & 2.758141 & 0.0118 \\
\hline C & 0.512914 & 0.566368 & 0.905621 & 0.3754 \\
\hline @TREND(1985) & -0.026409 & 0.033848 & -0.780212 & 0.4440 \\
\hline R-squared & 0.480869 & \multicolumn{2}{|c|}{ Mean dependent var } & -0.008000 \\
\hline
\end{tabular}

Null Hypothesis: D(U) has a unit root

Exogenous: None

Lag Length: 1 (Automatic_-based on SIC, maxlag=6)

\begin{tabular}{llll} 
& & $t$-Statistic & Prob. $^{*}$ \\
\hline Augmented Dickey-Fuller test statistic & -4.399596 & 0.0001 \\
\hline Test critical values: $\quad 1 \%$ level & -2.660720 & \\
\hline & $5 \%$ level & -1.955020 & \\
\hline & $10 \%$ level & -1.609070 & \\
\hline
\end{tabular}

*MacKinnon (1996) one-sided p-values.

Augmented Dickey-Fuller Test Equation

Dependent Variable: D(U,2)

Method: Least Squares

\begin{tabular}{|c|c|c|c|c|}
\hline Variable & Coefficient & Std. Error & $t$-Statistic & Prob. \\
\hline$\underline{\mathrm{D}(\mathrm{U}(-1))}$ & -0.842845 & 0.191573 & -4.399596 & 0.0002 \\
\hline $\mathrm{D}(\mathrm{U}(-1), 2)$ & 0.501249 & 0.180709 & 2.773790 & 0.0108 \\
\hline R-squared & 0.460409 & Mean dependent var & & -0.008000 \\
\hline Adjusted R-squared & 0.436948 & S.D. dependent var & & 1.571431 \\
\hline S.E. of regression & 1.179151 & Akaike info criterion & & 3.244085 \\
\hline Sum squared resid & 31.97914 & Schwarz criterion & & 3.341595 \\
\hline Log likelihood & -38.55106 & Hannan-Quinn criter. & & 3.271130 \\
\hline Durbin-Watson stat & 2.021484 & & & \\
\hline
\end{tabular}




\section{Appendix 3}

Estimation of State Space Models

Sspace: SS01

Method: Maximum likelihood (Marquardt)

\begin{tabular}{llllc} 
& Coefficient & Std. Error & z-Statistic & Prob. \\
\hline $\mathrm{C}(1)$ & -0.000273 & 3.200618 & $-8.52 \mathrm{E}-05$ & 0.9999 \\
\hline $\mathrm{C}(2)$ & -0.056874 & 3.425824 & -0.016602 & 0.9868 \\
& Final State & Root MSE & -Statistic & Prob. \\
\hline SV1 & 3.457560 & 707.1167 & 0.004890 & 0.9961 \\
\hline SV2 & 3.542440 & 707.1168 & 0.005010 & 0.9960 \\
\hline Log likelihood & -55.56132 & Akaike info criterion & 4.111523 \\
\hline Parameters & 2 & Schwarz criterion & 4.206680 \\
\hline Diffuse priors & 2 & Hannan-Quinn criter. & 4.140614 \\
\hline
\end{tabular}

Sspace: SS01

Method: Maximum likelihood (Marquardt)

Sample: 1985-2012

Included observations: 28

Convergence achieved after 25 iterations

\begin{tabular}{lclcc} 
& Coefficient & Std. Error & z-Statistic & Prob. \\
\hline $\mathrm{C}(1)$ & 0.656488 & 0.259550 & 2.529331 & 0.0114 \\
\hline $\mathrm{C}(2)$ & 0.975983 & 0.036640 & 26.63683 & 0.0000 \\
\hline SV1 & Final State & Root MSE & $z$-Statistic & Prob. \\
\hline Log likelihood & 6.831881 & 1.388528 & 4.920234 & 0.0000 \\
\hline Parameters & -50.44527 & Akaike info criterion & 3.746090 \\
\hline Diffuse priors & 2 & Schwarz criterion & 3.841248 \\
\hline
\end{tabular}

Sspace: SS01

Method: Maximum likelihood (Marquardt)

\begin{tabular}{lclcc} 
& Coefficient & Std. Error & z-Statistic & Prob. \\
\hline $\mathrm{C}(1)$ & 0.634768 & 0.241763 & 2.625574 & 0.0087 \\
& Final State & Root MSE & z-Statistic & Prob. \\
\hline SV1 & 7.000000 & 1.373530 & 5.096359 & 0.0000 \\
\hline Log likelihood & $\mathbf{- 5 5 . 5 4 1 4 1}$ & Akaike info criterion & & 4.038672 \\
\hline Parameters & 1 & Schwarz criterion & 4.086251 \\
\hline Diffuse priors & 1 & Hannan-Quinn criter. & 4.053217 \\
\hline
\end{tabular}


@signal u1=sv1

@state sv1 = c(1)*sv1(-1) + [var $=\exp (\mathrm{c}(2))]$

Sspace: SS02

Method: Maximum likelihood (Marquardt)

Sample: 1985-2012

Included observations: 28

Convergence achieved after 13 iterations

\begin{tabular}{|c|c|c|c|c|}
\hline & Coefficient & Std. Error & $z$-Statistic & Prob. \\
\hline$C(1)$ & 1.010108 & 0.011748 & 85.97780 & 0.0000 \\
\hline \multirow[t]{2}{*}{$C(2)$} & -1.869310 & 0.521787 & -3.582511 & 0.0003 \\
\hline & Final State & Root MSE & $z$-Statistic & Prob. \\
\hline SV1 & 6.335985 & 0.392721 & 16.13354 & 0.0000 \\
\hline Log likelihood & -20.90208 & \multicolumn{2}{|c|}{ Akaike info criterion } & 1.635863 \\
\hline Parameters & 2 & \multicolumn{2}{|c|}{ Schwarz criterion } & 1.731020 \\
\hline Diffuse priors & 1 & \multicolumn{2}{|c|}{ Hannan-Quinn criter. } & 1.664953 \\
\hline
\end{tabular}

@signal u1 = sv1

@state sv1 = sv1(-1) + [var $=\exp (\mathrm{c}(2))]$

Sspace: SS02

Method: Maximum likelihood (Marquardt)

Sample: 1985-2012

Included observations: 28

Convergence achieved after 9 iterations

\begin{tabular}{lllcc} 
& Coefficient & Std. Error & z-Statistic & Prob. \\
\hline $\mathrm{C}(2)$ & -1.837286 & 0.441786 & -4.158767 & 0.0000 \\
& Final State & Root MSE & z-Statistic & Prob. \\
\hline SV1 & 6.272583 & 0.399060 & 15.71839 & 0.0000 \\
\hline Log likelihood & -21.33485 & Akaike info criterion & & 1.595346 \\
\hline Parameters & 1 & Schwarz criterion & 1.642925 \\
\hline Diffuse priors & 1 & Hannan-Quinn criter. & & 1.609892 \\
\hline
\end{tabular}




\section{Author}

Mihaela Simionescu (Bratu) earned a $\mathrm{PhD}$ in economic cybernetics and statistics and is a senior researcher at the Institute for Economic Forecasting of the Romanian Academy and post-doctoral researcher in economics at the Romanian Academy. She is a member of the following professional associations: Romanian Regional Science Association, International Regional Science Association, Romanian Society of Econometrics, International Association of Scientific Innovation and Research, and General Association of Economists from Romania International Society of Bayesian Analysis.

\section{Kalmanov filter ali VAR-modeli za napovedovanje stopnje brezposelnosti v Romuniji?}

\section{Izvleček}

V prispevku predstavljamo v praksi pogost ekonomski problem. Ko imamo za isto spremenljivko več napovedi, pri odločanju pa potrebujemo samo eno, je za izbiro najboljše treba te napovedi oceniti. Namen prispevka je predlagati nekaj strategij za izboljšanje napovedi stopnje brezposelnosti v Romuniji s primerjalno analizo točnosti na podlagi dveh kvantitativnih metod, Kalmanovega filtra in vektorskih avtoregresijskih modelov (VAR-modelov). Pri prvi metodi je upoštevan razvoj komponent brezposelnosti, pri VAR-modelih pa medsebojne odvisnosti med stopnjo brezposelnosti in inflacijsko stopnjo. Po Grangerjevem testu vzročnosti je inflacijska stopnja v prvi diferenci vzrok za stopnjo brezposelnosti v prvi diferenci pri stacionarnih podatkih. Za napovedi stopnje brezposelnosti v obdobju 2010-2012 v Romuniji dobimo z VAR-modeli ( vseh različicah VAR-simulacij) bolj točne napovedi kot $s$ Kalmanovim filtrom na osnovi dveh modelov prostora stanj za vse mere točnosti. Upoštevajoč povprečno absolutno tehtano napako, so dinamične stohastične simulacije, uporabljene za napovedovanje brezposelnosti, ki temeljijo na VAR-modelu, najbolj točne. Pri drugi strategiji za izboljšanje začetnih napovedi, ki temelji na Kalmanovem filtru, so uporabljeni popravljeni podatki o brezposelnosti, transformirani s HodrickPrescottovim filtrom. Uporaba VAR modelov namesto različic Kalmanovega filtra je najboljša strategija za izboljšanje kakovosti napovedi stopnje brezposelnosti v Romuniji. Medsebojna povezanost med brezposelnostjo in inflacijo namreč ponuja uporabne informacije za napovedi, ki so zanesljivejše kot napovedi na osnovi razvoj brezposelnosti glede na gibanje njenih komponente (naravna brezposelnost in ciklična komponenta).

Ključne besede: napovedi, točnost, Kalmanov filter, Hodrick-Prescottov filter, VAR-modeli, stopnja brezposelnosti 